\title{
The influence of enriched environment on spatial memory in Swiss mice of different ages
}

\author{
A influência do ambiente enriquecido na memória espacial de camundongos Swiss em \\ diferentes faixas etárias
}

Alessandra Fernandes Druzian', José Aparecido de Oliveira Melo', Albert Schiaveto de Souza²

\begin{abstract}
The objective of this study was to evaluate the influence of enriched environment on spatial memory acquisition in mice of three different age groups. Weanling, young, and young adult female Swiss mice were housed in a standard control or enriched environment for 50 days, and their spatial memory was tested with the Morris Water Maze. We did not observe an experimental effect for spatial memory acquisition, and there was neither an effect of time of analysis nor an interaction between experimental group and time of analysis. Regarding effects of experimental group and training day in relation to latency in finding the hidden platform, we did find an effect in the experimental young adult mice group ( $p=0.027$ ), but there was no interaction between these factors in all three groups. Based on these findings environmental enrichment did not enhance spatial memory acquisition in female Swiss mice in the tested age groups.
\end{abstract}

Keywords: mice, memory, spatial behavior, hippocampus.

\section{RESUMO}

O objetivo deste estudo foi avaliar a influência do ambiente enriquecido na aquisição da memória espacial de camundongos em três diferentes faixas etárias. Camundongos fêmeas Swiss recém-desmamados, jovens e adultos jovens foram alojados em ambiente controle ou em ambiente enriquecido durante 50 dias, e sua memória espacial foi testada por meio do Labirinto Aquático de Morris. Não houve efeito do grupo experimental na aquisição de memória espacial, do momento de análise, tampouco da interação entre o grupo experimental e o momento de análise. Quanto aos efeitos do grupo experimental e do dia de treino em relação à latência para encontrar a plataforma escondida, houve efeito do grupo experimental apenas para o grupo experimental adulto jovem ( $p=0,027$ ), com menor latência do grupo controle, porém sem interação entre esses fatores para todos os grupos. O enriquecimento ambiental não interferiu na aquisição de memória espacial de camundongos fêmeas Swiss nas faixas etárias analisadas.

Palavras-chave: camundongos, memória, comportamento espacial, hipocampo.

The increase in life expectancy has been influenced by strategies to minimize aging's effects on memory by means of animal models such as mice. Enriched environment (EE) rearing is one of those strategies; in this paradigm, mice live in conditions that facilitate sensorial, visual, cognitive, and motor stimulation ${ }^{1}$. Cognitive stimuli including spatial complexity, novelty, and physical activity affect brain plasticity. In turn, brain plasticity promotes hippocampal neurogenesis $^{2}$ and consequently positively influences spatial memory, a hippocampal-dependent process that decreases with aging ${ }^{3,4}$. However, EE can also produce negative results or no effect, depending on the resources used for enrichment, variables studied, animal strain used, and environmental enrichment duration ${ }^{5}$.

Some studies have evaluated the effects of environmental enrichment on spatial memory by using different age groups of mice in the same research ${ }^{6,7,8,9,10}$, with housing periods similar to that used here ${ }^{6,7,8}$. However, the majority of these studies have only evaluated mice from young ages to middle age and senescence, when memory impairment has already started. Improvements in spatial memory were only observed in middle-aged ${ }^{6.8}$ and aged mice ${ }^{7}$ in those studies. In this research, we opted to submit weanling, young, and young adult female mice to EE with the intention of evaluating whether

\footnotetext{
${ }^{1}$ Universidade Federal de Mato Grosso do Sul, Serviço de Fisioterapia, Campo Grande MS, Brazil;

${ }^{2}$ Universidade Federal de Mato Grosso do Sul, Faculdade de Ciências Biológicas e da Saúde, Campo Grande MS, Brazil.

Correspondence: Alessandra Fernandes Druzian; Rua Dr. Werneck, 104 / ap. 3401; 79060-300 Vila Albuquerque, Campo Grande MS, Brasil; E-mail: aledruzian@gmail.com

Conflict of interest: There is no conflict of interest to declare.

Received 21 July 2014; Received in final form 04 March 2015; Accepted 24 March 2015.
} 
EE influences spatial memory acquisition prior to the onset of memory impairment and determining if there is an interaction between $\mathrm{EE}$ and the age during $\mathrm{EE}$.

\section{METHOD}

\section{Animals}

Forty-seven female Swiss mice from three different age groups: weanling (21 days), young (3 months) and young adult ( 7 months) were used. These animals were supplied by the Central Vivarium of the Universidade Federal de Mato Grosso do Sul, and the study was conducted there. The animals were randomly housed in a standard control environment (CE) or EE, as follows: weanling $\mathrm{CE}(\mathrm{n}=8)$, weanling $\mathrm{EE}(\mathrm{n}=8)$, young $\mathrm{CE}(\mathrm{n}=8)$, young $\mathrm{EE}(\mathrm{n}=8)$, young adult $\mathrm{CE}(\mathrm{n}=7)$, and young adult $\mathrm{EE}(\mathrm{n}=8)$. The $\mathrm{CE}$ and $\mathrm{EE}$ groups were both housed for 50 days. This research was approved by the Animal Use Ethics Committee of the Universidade Federal de Mato Grosso do Sul (protocol no 336/2011).

\section{Procedures}

\section{EE and $C E$}

The CE consisted of a standard rodent box (31 cm wide, $39 \mathrm{~cm}$ long, and $18 \mathrm{~cm}$ high) lined with shavings, and food and water were available ad libitum. The EE was an ample metallic cage with two levels $(60 \mathrm{~cm}$ wide, $81 \mathrm{~cm}$ long, and $46 \mathrm{~cm}$ high) containing two sets of stairs for second-level access (where water and food were available ad libitum) ${ }^{10,11}$, three catwalks, one running wheel, and one trampoline. The lower level was lined with shavings.

The cage was also supplied with toys commercially available for children, tunnels, and nesting material (paper). The toys and nesting materials were changed two times per week during cage cleaning ${ }^{11,12}$. Approximately 10 to 15 different objects were placed, along with 4 paper sheets or crumbled pieces of nesting material in every change. The light cycle was controlled under a 12-hour light/dark cycle, and the temperature was maintained at $21 \pm 3^{\circ} \mathrm{C}$.

\section{Morris water maze}

The Morris Water Maze (MWM) $)^{13}$ was a black polyethylene circular tank adapted for mouse dimensions (101 cm diameter and $53 \mathrm{~cm}$ high) that was filled with room temperature water $\left(21 \pm 3^{\circ} \mathrm{C}\right)$ before training sessions. This tank was virtually subdivided into four quadrants. A black platform was attached in one of the quadrants (11 cm diameter and $19.5 \mathrm{~cm}$ high), with the superior part located $\sim 1 \mathrm{~cm}$ below the water surface (hidden from the mouse's view), and its location remained the same during all training days and final tests ${ }^{11}$. The platform had a rough surface that allowed the mice to easily climb onto it once its presence was detected. On the internal walls of the tank, above the water and on all four quadrants, images were fixed to serve as spatial reference points.

\section{Spatial memory task}

To test spatial memory in the MWM, we used an adapted protocol comprised of three training trials per day over 5 consecutive days, with an inter-trial interval of 30 seconds $^{11,14}$. The training trial was performed beginning on the $40^{\text {th }}$ day of housing. The final spatial memory test, performed to verify acquisition of spatial memory after training, was on the $50^{\text {th }}$ day of housing, 4 days after training trials had finished. It was conducted in three series with an inter-series interval of 30 seconds $^{11}$.

During the training trials and final test, mice were individually placed in one of three randomly chosen quadrants (except the hidden platform one), facing the border of the tank. Each mouse had 90 seconds to find the hidden platform in each training trial and in each series of the final test. If the mouse could not find it, it was manually placed on the platform by the examiner, where it stayed for 30 seconds ${ }^{10,11}$. Afterward, the animal was placed into a standard rodent box, where it rested for 30 seconds, and then returned to the tank, if it had not yet completed the third trial/series. The task was considered complete when animals found and climbed onto the platform. The training trials and test series were conducted by two examiners; one placed and removed the animals from the tank, and the other measured the latency period to find the hidden platform and recorded the data. The latency period to find the hidden platform was measured by a digital chronometer ${ }^{11}$ in each training trial and test series. Immediately after completing the three training trials, the animals were removed from the platform, dried with a cloth towel, and warmed by an incandescent lamp placed over a standard rodent box, before they were returned to their respective cages. All training and tests were performed during the light phase of the light/dark period. The animals were euthanized after they completed the final spatial memory task.

\section{Statistical analysis}

Evaluations of the experimental group effect, animal's age effect, and the interaction between these factors in relation to the latency period to find the hidden platform in the MWM and on the final test were performed by means of two-way variance analysis (ANOVA). Evaluations of the experimental group effect, training day effect, and the interaction between these factors in relation to the latency period to find the hidden platform in the MWM were performed by means of two-way repeated measure ANOVA and Tukey's post-hoc testing between groups. We used SigmaStat software (version 3.5), considering a significance level of $5 \%$. All data are presented as mean \pm standard error of mean.

\section{RESULTS}

There was no experimental group effect regarding the latency period to find the MWM hidden platform on the final test day. That is, independent of animal age, there was no 
difference between the CE and EE groups $(p=0.471)$. There was also no effect concerning the age animals were housed $(p=0.341)$ and there was no interaction between these variables $(\mathrm{p}=0.590$, Figure 1 and Table 1$)$.

For weanling animals, there was no experimental group effect $(p=0.481)$ or training day effect $(p=0.448)$. There was also no interaction between the experimental groups and training days in relation to the latency period to find the hidden platform ( $p=0.827$, Figure 2 ). The same result was observed for young animals $(\mathrm{p}=0.301, \mathrm{p}=0.053$, and $\mathrm{p}=0.941$, respectively; Figure 3). Regarding young adult animals, there was an experimental group effect ( $p=0.027$ ); however there was neither a training day effect ( $\mathrm{p}=0.846)$ nor an interaction between the experimental group and training days in relation to the latency period to find the hidden platform ( $p=1.000$, Figure 4). Regarding the group effect of young adult animals, the latency period of CE animals was significantly lower than that measured in the EE group animals on general training days (Tukey's post-hoc, $\mathrm{p}<0.05$ ). The latencies to find the hidden platform on each training day are presented in Table 2.

\section{DISCUSSION}

EE has been widely studied to evaluate whether it can stave off memory declines related to age. Here, we investigated the influence of EE on spatial memory in weanling, young, and young adult female Swiss mice. We did not observe statistically significant alterations of spatial memory in the EE groups relative to the controls or among the age groups in the final spatial memory test. Regarding MWM training trials before spatial memory testing, although there was an experimental group effect for young adult mice (lower latency

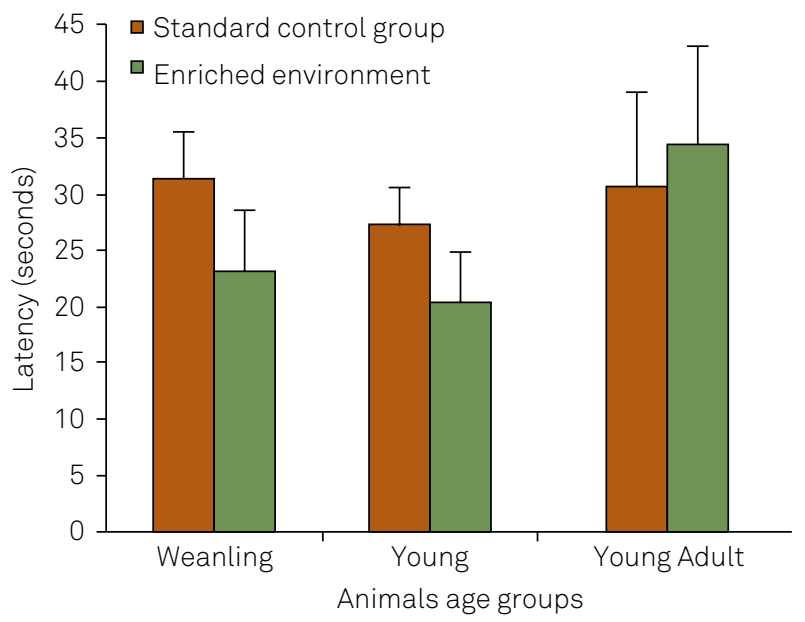

CE: Standard Control Environment; EE: Enriched Environment.

Figure 1. Latency period to find the hidden platform for the control and enriched environments between weanling, young, and young adult mice on the day of the memory test after 4 days of training. The columns and bars represent the means and standard errors of means. period of the control group to find the hidden platform), there was no statistical significance for this interaction in the final spatial memory test.

Studies evaluating the ability of EE to prevent age-related memory decline in mice have reported contradictory results. While some found significant positive effects on spatial memory only in aged mice ${ }^{7}$, other studies also demonstrated such effects in middle-aged mice ${ }^{6}$. Still, some studies have reported improvement on spatial task execution by both young and young adult mice groups ${ }^{8,9,10,12}$. However, studies conducted with mice in age groups similar to those used here did not find significant results for spatial memory tasks ${ }^{7,8,15}$.

EE duration seems to influence the magnitude of behavior effects in mice, as do the age when they are housed ${ }^{16}$ and the EE protocols used ${ }^{17}$. A long duration EE is associated with higher habituation to novelty and hippocampal neurogenesis in mice ${ }^{18}$. Despite this fact, there is considerable variation among studies in relation to housing periods in different studies. We hypothesized that a 7-week housing period would be sufficient to improve spatial memory in weanling, young, and young adult mice. Nevertheless, we did not obtain significant results, which is in accordance with studies that used similar housing periods (from six to eight weeks) and complex EE protocols (cognitive and physical stimulation and social interaction $)^{7,8,15}$. On the other hand, those studies with significant results in relation to spatial memory, despite using similar

Table 1. Latencies (seconds) to find the hidden platform in the final Morris Water Maze test.

\begin{tabular}{lccc}
\hline & Control group & Enriched group & $P$ \\
\hline Weanling & $31.37 \pm 4.09$ & $23.16 \pm 5.34$ & 0.243 \\
Young & $26.54 \pm 4.08$ & $20.33 \pm 4.42$ & 0.319 \\
Young adult & $30.67 \pm 8.34$ & $34.29 \pm 8.75$ & 0.771 \\
\hline
\end{tabular}

Note: data are presented as mean \pm standard error of the mean.

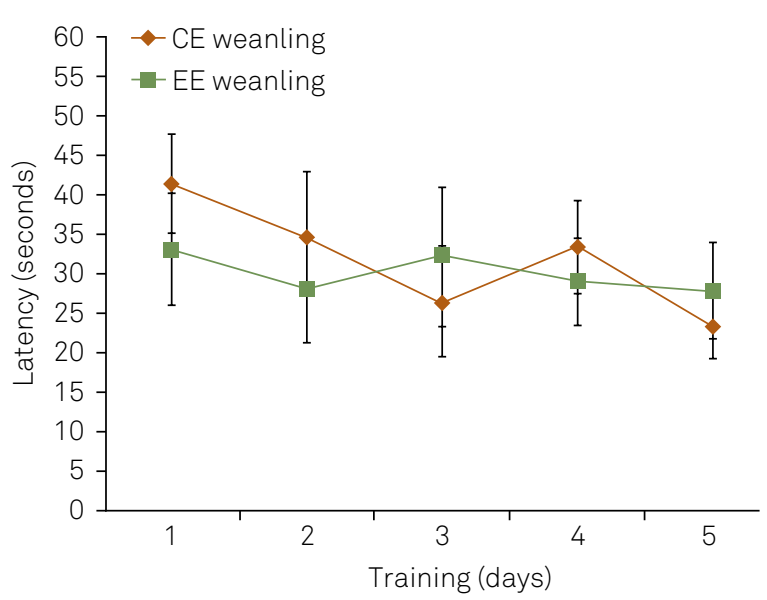

CE: Standard Control Environment; EE: Enriched Environment.

Figure 2. Latency period to find the hidden platform for the weanling control and enriched groups according to the training days. The symbols and bars represent the means and standard errors of means. 
enrichment protocols, maintained the EE for longer periods, from 2 to 21 months ${ }^{9,10,12}$. Some of the groups that reported significant results with an EE period and enrichment protocol similar to this study ${ }^{6,7,8}$ evaluated middle-aged and aged mice.

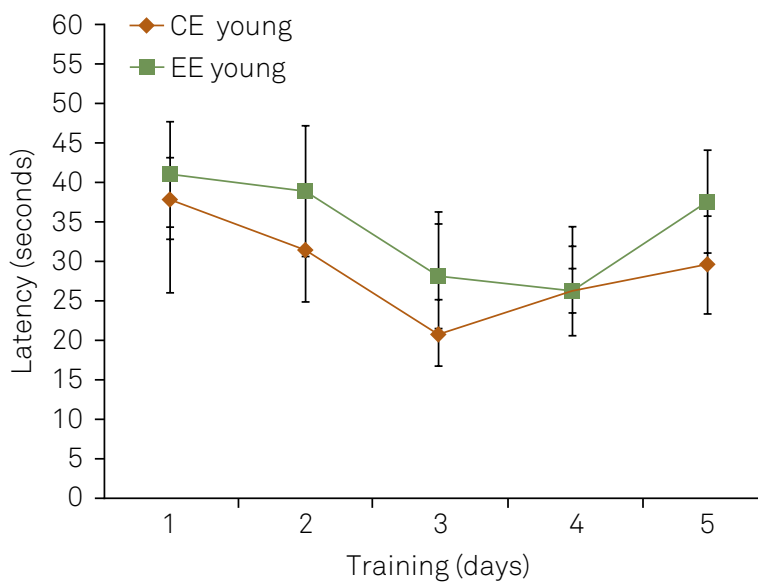

CE: Standard Control Environment; EE: Enriched Environment.

Figure 3. Latency period to find the hidden platform for the young control and enriched groups according to the training days. The symbols and bars represent the means and standard errors of means.

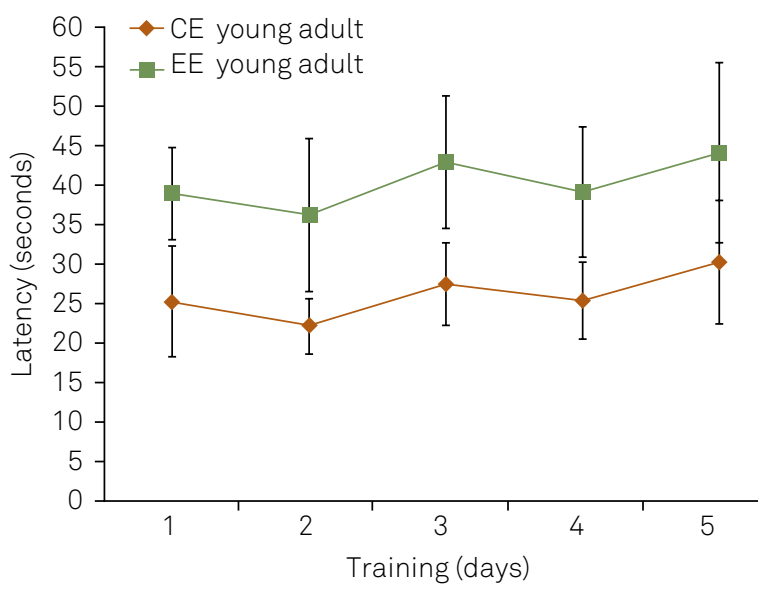

CE: Standard Control Environment; EE: Enriched Environment.

Figure 4. Latency period to find the hidden platform for the young adult control and enriched groups according to the training days. The symbols and bars represent the means and standard errors of means.
This might explain the discrepant result; effects might not be seen until memory decline begins around middle age ${ }^{19}$.

In addition to EE protocols, considering each species or strains' behavior is necessary when designing studies. Due to their natural tendency to dig and build nests ${ }^{20}$, mice prefer nesting materials over any others ${ }^{21}$. This explains the different results between our study and that of Kulesskaya et al. ${ }^{12}$, who found better MWM performance for enriched weanling mice using only nesting material as an enrichment strategy. However, complex enrichment applied over brief periods seems to benefit mice starting only at middle age ${ }^{8}$ when memory decline begins. Nevertheless, physical stimulation seems to benefit spatial memory at ages when there is still no memory impairment ${ }^{22}$, likely by promoting changes in glial cells involved in synaptic remodeling and affecting brain plasticity ${ }^{23}$. Studies that used more than one running wheel in their EE protocol reported positive results ${ }^{8,9,10}$. This could be explained by enhanced overall effects due to greater access to physical stimulation, which is associated with higher exposure time to the stimulus. The one running wheel available might have been insufficient for the number of mice housed.

Stressful situations such as novelty exposure in EE and aversion to water on $\mathrm{MWM}^{24}$, as well as hormonal alterations related to aging ${ }^{25}$, inhibit the process of long-term potentiation, which harms learning and spatial memory ${ }^{24,25}$. Super-enrichment, achieved by introducing new objects, might increase stress and aggressiveness among mice, and static and repetitive objects might attenuate behavioral responses to novelty ${ }^{20}$. Pre-training in different spatial memory tasks might improve MWM task performance ${ }^{24}$, mitigating those negative effects (impaired performance due to water aversion may be mistakenly interpreted as deficient spatial learning).

Female mice seem to be more negatively susceptible to stress-causing factors ${ }^{26}$. Lin et al. ${ }^{27}$ verified an anxiety effect in female mice submitted to EE and depressive behavior due to longer immobility time on the forced swim test. Although we did not evaluate emotional behavior, we observed an increase in immobility and floating time during the MWM among EE animals. This might explain the higher latency period to find the hidden platform for young adult EE mice relative to the control group during training trials. Furthermore, chronic stress caused by EE (exposure to many objects) and aversion to water during $\mathrm{MWM}$ ) and absence of pre-training

Table 2. Latencies (seconds) to find the hidden platform on each Morris Water Maze training day.

\begin{tabular}{lcccccc}
\hline \multirow{2}{*}{ Training day } & \multicolumn{3}{c}{ Control group } & \multicolumn{3}{c}{ Enriched group } \\
\cline { 2 - 7 } & Weanling & Young & Young adult & Weanling & Young & Young adult \\
\hline 1 & $41.33 \pm 6.34$ & $37.71 \pm 5.11$ & $25.24 \pm 6.95$ & $33.04 \pm 7.10$ & $40.75 \pm 6.63$ & $38.92 \pm 5.77$ \\
2 & $34.62 \pm 8.29$ & $31.29 \pm 6.58$ & $22.14 \pm 3.52$ & $28.08 \pm 6.97$ & $38.67 \pm 8.31$ & $36.17 \pm 9.63$ \\
3 & $26.21 \pm 6.76$ & $20.75 \pm 4.17$ & $27.47 \pm 5.25$ & $32.17 \pm 8.80$ & $28.00 \pm 6.60$ & $42.87 \pm 8.36$ \\
4 & $33.37 \pm 5.82$ & $26.12 \pm 2.76$ & $25.38 \pm 4.86$ & $29.00 \pm 5.52$ & $26.12 \pm 5.57$ & $39.12 \pm 8.22$ \\
5 & $23.33 \pm 4.06$ & $29.38 \pm 6.13$ & $30.24 \pm 7.79$ & $27.84 \pm 6.10$ & $37.33 \pm 6.53$ & $44.08 \pm 11.38$ \\
\hline
\end{tabular}

Note: Data are presented as mean \pm standard error of the mean. There was no interaction between experimental group and training days: weanling $(p=0.827)$, young $(p=0.941)$, and young adult $(p=1.000)$. 
tasks previously to MWM tasks might explain this unexpected result. Gresack et al. ${ }^{9}$ and Harburger et al. ${ }^{8}$ observed longer swim speeds and shorter swim times, respectively, in one of their control groups relative to their enriched ones. The outcome was better MWM performance by the control groups. However, the enriched group described by Harburger et al. ${ }^{8}$ overcame its control group during training trials. In both studies, the authors performed more training trials per day, which might explain why the enriched young adult mice in our study did not overcome their controls over training days.

Moreover, the EE housing period could have been insufficient for the super-enrichment habituation of female mice in the age groups studied. This would be in accordance with other studies that used female mice, age groups, and EE durations similar to ours ${ }^{8,15}$.

Exposure to novelty and non-familiar situations can induce anxiety, and mice responses vary by $\operatorname{strain}^{28}$. Swiss mice seem to be resistant to environment variations relative to other strains ${ }^{29}$, showing an inferior performance in MWM tasks in comparison to other strains ${ }^{11,30}$, and requiring a longer enrichment period to achieve significant results ${ }^{10}$.

In summary, EE did not improve spatial memory acquisition in female Swiss mice in the analyzed age groups. It is likely that the lack of significant results was related to the insufficient EE period. Moreover, the analyzed age groups could have had significant spatial memory results if there had been more running wheels to promote physical activity.

\section{Acknowledgments}

Our sincere thanks to the staff of the Biomorphophysiology Laboratory and the Central Vivarium of the Universidade Federal de Mato Grosso do Sul; this research would not have been possible without their help.

\section{References}

1. Nithianantharajah J, Hannan AJ. Enriched environments, experience-dependent plasticity and disorders of the nervous system. Nat Rev Neurosci. 2006;7(9):697-709. http://dx.doi.org/10.1038/nrn1970

2. Kempermann G, Faber K, Ehninger D, Babu H, Leal-Galicia $\mathrm{P}$, Garthe Aet al. Why and how physical activity promotes experience-induced brain plasticity. Front Neurosci. 2010;4:189. http://dx.doi.org/10.3389/fnins.2010.00189

3. Heo S, Prakash RS, Voss MW, Erickson KI, Ouyang C, Sutton BP et al. Resting hippocampal blood flow, spatial memory and aging. Brain Res. 2010;1315:119-27. http://dx.doi.org/10.1016/j.brainres.2009.12.020

4. Foster TC, DeFazio RA, Bizon JL. Characterizing cognitive aging of spatial and contextual memory in animal models. Front Aging Neurosci. 2012;4:12. http://dx.doi.org/10.3389/fnagi.2012.00012

5. Tsai PP, Pachowsky U, Stelzer HD, Hackbarth H. Impact of environmental enrichment in mice. 1: effect of housing conditions on body weight, organ weights and haematology in different strains. Lab Anim. 2002;36(4):411-9. http://dx.doi.org/10.1258/002367702320389071

6. Frick KM, Stearns NA, Pan JY, Berger-Sweeney J. Effects of environmental enrichment on spatial memory and neurochemistry in middle-aged mice. Learn Mem. 2003;10(3):187-98. http://dx.doi.org/10.1101//m.50703

7. Harburger LL, Lambert TJ, Frick KM. Age-dependent effects of environmental enrichment on spatial reference memory in male mice. Behav Brain Res. 2007;185(1):43-8. http://dx.doi.org/10.1016/j.bbr.2007.07.009

8. Harburger LL, Nzerem CK, Frick KM. Single enrichment variables differentially reduce age-related memory decline in female mice. Behav Neurosci. 2007;121(4):679-88. http://dx.doi.org/10.1037/0735-7044.121.4.679

9. Gresack JE, Kerr KM, Frick KM. Life-long environmental enrichment differentially affects the mnemonic response to estrogen in young, middle-aged, and aged female mice. Neurobiol Learn Mem. 2007;88(4):393-408. http://dx.doi.org/10.1016/j.nlm.2007.07.015

10. Diniz DG, Foro CA, Rego CMD, Gloria DA, Oliveira FR, Paes JM et al. Environmental impoverishment and aging alter object recognition, spatial learning, and dentate gyrus astrocytes. Eur J Neurosci. 2010;32(3):509-19. http://dx.doi.org/10.1111/j.1460-9568.2010.07296.x
11. Santos AF. Influência do enriquecimento ambiental na aquisição, retenção e evocação da memória espacial em duas linhagens de camundongos [dissertação]. Campo Grande: Universidade Católica Dom Bosco; 2009.

12. Kulesskaya N, Rauvala H, Voikar V. Evaluation of social and physical enrichment in modulation of behavioural phenotype in C57BL/6J female mice. PLoS ONE. 2011;6(9):e24755. http://dx.doi.org/10.1371/journal.pone.0024755

13. Morris R. Spatial localization does not require the presence of local cues. Learn Motiv. 1981;12:239-60. http://dx.doi.org/10.1016/0023-9690(81)90020-5

14. Rossato JI, Bevilaqua LRM, Medina JH, Izquierdo I, Cammarota M. Retrieval induces hippocampal-dependent reconsolidation of spatial memory. Learn Mem. 2006;13(4):431-40. http://dx.doi.org/10.1101/lm.315206

15. Prusky GT, Reidel C, Douglas RM. Environmental enrichment from birth enhances visual acuity but not place learning in mice. Behav Brain Res. 2000;114(1-2):11-5. http://dx.doi.org/10.1016/S0166-4328(00)00186-8

16. Amaral OB, Vargas RS, Hansel G, Izquierdo I, Souza DO. Duration of environmental enrichment influences the magnitude and persistence of its behavioral effects on mice. Physiol Behav. 2008;93(1-2):388-94. http://dx.doi.org/10.1016/j.physbeh.2007.09.009

17. Simpson J, Kelly JP. The impact of environmental enrichment in laboratory rats: behavioural and neurochemical aspects. Behav Brain Res. 2011;222(1):246-64. http://dx.doi.org/10.1016/j.bbr.2011.04.002

18. Kempermann G, Gage FH. Experience-dependent regulation of adult hippocampal neurogenesis: effects of long-term stimulation and stimulus withdrawal. Hippocampus. 1999;9(3):321-32. http://dx.doi. org/10.1002/(SICI)1098-1063(1999)9:3<321::AID-HIP011>3.0.CO;2-C

19. Frick KM, Burlingame LA, Arters JA, Berger-Sweeney J. Reference memory, anxiety and estrous cyclicity in C57BL/6NIA mice are affected by age and sex. Neuroscience. 2000;95(1):293-307. http://dx.doi.org/10.1016/S0306-4522(99)00418-2

20. Hutchinson EK, Avery AC, Vandewoude S. Environmental enrichment for laboratory rodents. ILAR J. 2005;46(2):148-61. http://dx.doi.org/10.1093/ilar.46.2.148

21. Olsson IA, Dahlborn K. Improving housing conditions for laboratory mice: a rewiew of "environmental enrichment". Lab Anim. 2002;36(3):243-70. http://dx.doi.org/10.1258/002367702320162379 
22. Mello PB, Benetti F, Cammarota M, Izquierdo I. Effects of acute and chronic exercise and stress on different types of memory in rats. An Acad Bras Cienc. 2008;80(2):301-9.

23. Bernardi C, Tramontina AC, Nardin P, et al. Treadmill exercise induces hippocampal astroglial alterations in rats. Neural Plast. 2013(2013):id709732. http://dx.doi.org/10.1155/2013/709732

24. Hölscher C. Stress impairs performance in spatial water maze learning tasks. Behav Brain Res. 1999;100(1-2):225-35. http://dx.doi.org/10.1016/S0166-4328(98)00134-X

25. Sadeghian R, Fereidoni M, Soukhtanloo M, Azizi-Malekabadi H, Hosseini M. Decreased nitric oxide levels in the hippocampus may play a role in learning and memory deficits in ovariectomized rats treated by a high dose of estradiol. Arq Neuropsiquiatr. 2012;70(11):874-9. http://dx.doi.org/10.1590/S0004-282X2012001100010

26. Adamec R, Head D, Blundell J, Burton P, Berton O. Lasting anxiogenic effects of feline predator stress in mice: sex differences in vulnerability to stress and predicting severity of anxiogenic response from the stress experience. Physiol Behav. 2006;88(1-2):12-29. http://dx.doi.org/10.1016/j.physbeh.2006.03.005

27. Lin EJD, Choi E, Liu X,; Martin A, During MJ. Environmental enrichment exerts sex-specific effects on emotionality in C57BL/6J mice. Behav Brain Res. 2011;216(1):349-57. http://dx.doi.org/10.1016/j.bbr.2010.08.019

28. Ennaceur A, Michalikova S, van Rensburg R, Chazot PL. Models of anxiety: responses of mice to novelty and open spaces in a 3D maze. Behav Brain Res. 2006;174(1):9-38. http://dx.doi.org/10.1016/j.bbr.2006.07.001

29. Silva CF, Duarte FS, Lima TCM, Oliveira CL. Effects of social isolation and enriched environment on behavior of adult Swiss mice do not require hippocampal neurogenesis. Behav Brain Res. 2011;22(1)5:85-90. http://dx.doi.org/10.1016/j.bbr.2011.07.007

30. Van Dam D, Lenders G, De Deyn PP. Effect of Morris water maze diameter on visual-spatial learning in different mouse strains. Neurobiol Learn Mem. 2006;85(2):164-72. http://dx.doi.org/10.1016/j.nlm.2005.09.006 